\title{
Outcrossing in an ant pollinated clonal orchid
}

\author{
R. Peakall* and \\ S. H. James
}

Botany Department, The University of Western Australia, Nedlands 6009 WA, Australia.

The orchid Leporella fimbriata propagates vegetatively by means of underground tubers to form dense but discrete patches of plants. Electrophoretic analysis revealed the presence of large clones extending up to $16 \mathrm{~m}^{2}$. Individual clones could constitute an entire patch. Most pollinator movements were within clones. As the orchid is self-compatible this suggested selfing rates as high as $\mathbf{7 0}$ per cent. However, the adult population genetic structure did not reflect high levels of selfing. Rather, the fixation index, chi-square tests for conformance to Hardy-Weinberg conditions and gene correlation estimates were consistent with panmictic expectations. It is suggested that some outcossing mediated by ant pollinators, extensive seed flow anticipated for the minute wind dispersed seeds, and elimination of selfed progeny reduce the effects of selfing.

\section{INTRODUCTION}

Failure to recognize and understand clonality can lead to incorrect interpretations in a broad range of ecological, genetical and evolutionary studies (Silander, 1979; Cook, 1983; Handel, 1985). For example, within-clone gene transfer may reduce the frequency of outcrossing events resulting in reduced seed set in a self-incompatible species, while producing high levels of selfing in a selfcompatible species. These patterns have been demonstrated in simulations by Handel (1985), who showed that for the self-incompatible insectpollinated species Trifolium repens an increase in clone size resulted in a reduction of successful pollinations, while in the self-compatible windpollinated Carex platyphylla there was a shift from outbreeding towards inbreeding.

Leporella fimbriata is a widespread monotypic terrestrial orchid of southern Australia. Populations of the orchid consist of discrete patches often containing hundreds of plants. Only a small percentage of plants flower each season and flower numbers may be highly variable with some populations showing enhanced flowering after a bush fire. One to three flowers $2-2 \cdot 5 \mathrm{~cm}$ across are borne on

\footnotetext{
* Present address and address for reprints: School of Biological
} Sciences Macquarie University, 2109 NSW, Australia. erect scapes $12-30 \mathrm{~cm}$ high. This study had three goals. First, to examine the clonal substructuring of patches since the orchid reproduces vegetatively by the formation of 1-3 daughter tubers which develop up to $14 \mathrm{~cm}$ from the parent tuber (Peakall, 1987, 1988). Second, to examine the effect of pollinator movement within these patches on outcrossing rates. Third, the effect of pollinator movement was of special interest because of the unique pollination system involving pseudocopulation by winged male ants (Peakall et al., 1987; Peakall, 1988). Ants are generally regarded as being incapable of cross-pollination (Hickman, 1974, see also review by Beattie, 1982).

\section{MATERIALS AND METHODS}

Self-compatibility was determined by comparing seed set and the percentage of seeds with embryos in samples of self and cross pollinated fruits. Details of the pollination biology of L. fimbriata are provided in Peakall (1988). Pollen vector flights were measured between flowers, and between flowers and vegetation. Where possible, genotypes of donor and recipient flowers were determined electrophoretically.

Material from four sites on the edge of the Perth Metropolitan area, Western Australia was 
analysed electrophoretically. The Bickley (B), Lesmurdie (L) and Canningmills 3 (C3) sites were located in the Darling Range East of Perth with the most distant site, Kwinana 2 (KW2) occurring on the Swan Coastal Plain some $30 \mathrm{~km}$ from the other populations. Further details of locations and habitat are provided in Peakall $(1987,1988)$. Approximately $0.25 \mathrm{~cm}^{2}$ of freshly collected leaf material, stored at $0-4^{\circ} \mathrm{C}$, was homogenized in $18 \mu \mathrm{l}$ of chilled freshly prepared extraction buffer modified from Cheliak and Pitel (1984). Homogenates were absorbed into Chromatography paper wicks, blotted on filter paper, and inserted into 12.5 per cent starch gels (Sigma) for horizontal electrophoresis. Electophoresis buffers were modified from Selander et al. (1971) and Shields et al. (1983). Enzyme stain recipes were modified from Shaw and Prasad (1979) and Moran and Hopper (1983). Full details are provided in Peakall (1987).

As in orchids generally, the minute seeds of Leporella lack endosperm and require mycorrhizal infection for germination in the wild. Attempts to germinate the seeds of Leporella using asymbiotic and symbiotic techniques have so far been unsuccessful, so, formal genetic analysis of the banding patterns and standard estimates of outcrossing based on progeny arrays were not possible. Four polymorphic loci, Got-2, Est-3, Pgi and 6Pgd exhibited simple banding patterns for which the genetic basis of variation could be inferred. Side by side comparisons of bulked pollinia from within inflorescences and leaf material augmented these interpretations. Genotypes were assigned to each of these loci for all individuals. Loci and alleles were numbered from the most anodal to the least anodal. Pgm exhibited consistent polymorphic multiple band patterns and was used as an additional phenotypic marker.

Population sample sets, which avoided replication within clones, were assembled for the four sites by sampling only once from each discrete patch. The percentage of unique genotypes was calculated for each site. This index represented the degree of individuality detectable in the sample set and provided a measure of the sensitivity of detecting individual clones at the site, These sample sets were also used in the following statistical analyses. The fixation index $F$ and conformance tests for Hardy-Weinberg equilibrium were calculated using the computer program BIOSYS-1 (Swofford and Selander, 1981). Relative outcrossing estimates under the assumption of no selection between fertilization and the adult stage were calculated as $t=(1-F) /(1+F)$ (Jain, 1979). Wright's (1951) parameters, calculated according to the recently described estimators of Weir and Cockerham (1984), and Nei's (1973) gene diversity statistics were estimated by treating each of the four sites as subpopulations.

Two discrete patches at Bickley known simply as $\mathrm{A}$ and $\mathrm{B}$ and consisting of some 500 individuals each, were mapped. Subsequently, 100 individuals were randomly selected in each for electrophoretic analysis. Less intensive multiple sampling within other colonies was undertaken at several of the sites to determine the extent of individual clones. Estimates of the potential extent of selfing were made by comparing the distributions of clonal diameters and interpatch distances with the flight distribution of the pollen vector.

\section{RESULTS}

Four polymorphic loci and the phenotyic Pgm marker were sufficient for detecting clones. Genotypic individuality of the samples varied from 67 to 80 per cent, based on the 4 loci, while, the total detected individuality was not less than 89 per cent and as high as 97 per cent when Pgm was utilized (table 1).

Fig. 1 shows the pattern of genotypic variation observed in two patches of L. fimbriata. All but three plants at $\mathrm{A}$ were of the same genotype being a double heterozygous clone covering an area of some $16 \mathrm{~m}^{2}$ : the other three were all different. At patch $\mathrm{B}$ two genotypes predominated, each cover-

Table 1 Detected genotypic and phenotypic individuality (I) of Leporella fimbriata clones based on electrophoretic band patterns

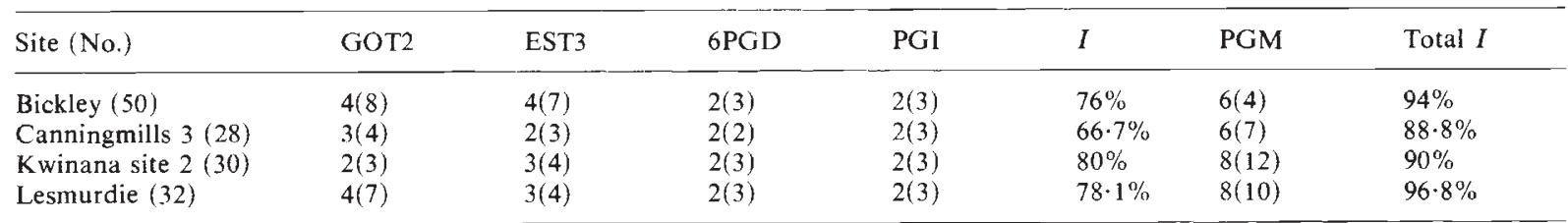

The numbers preceding the parentheses for each locus represent the observed number of alleles (bands for PGM) while the numbers in parentheses represent the observed number of genotypes (phenotypes for PGM). 

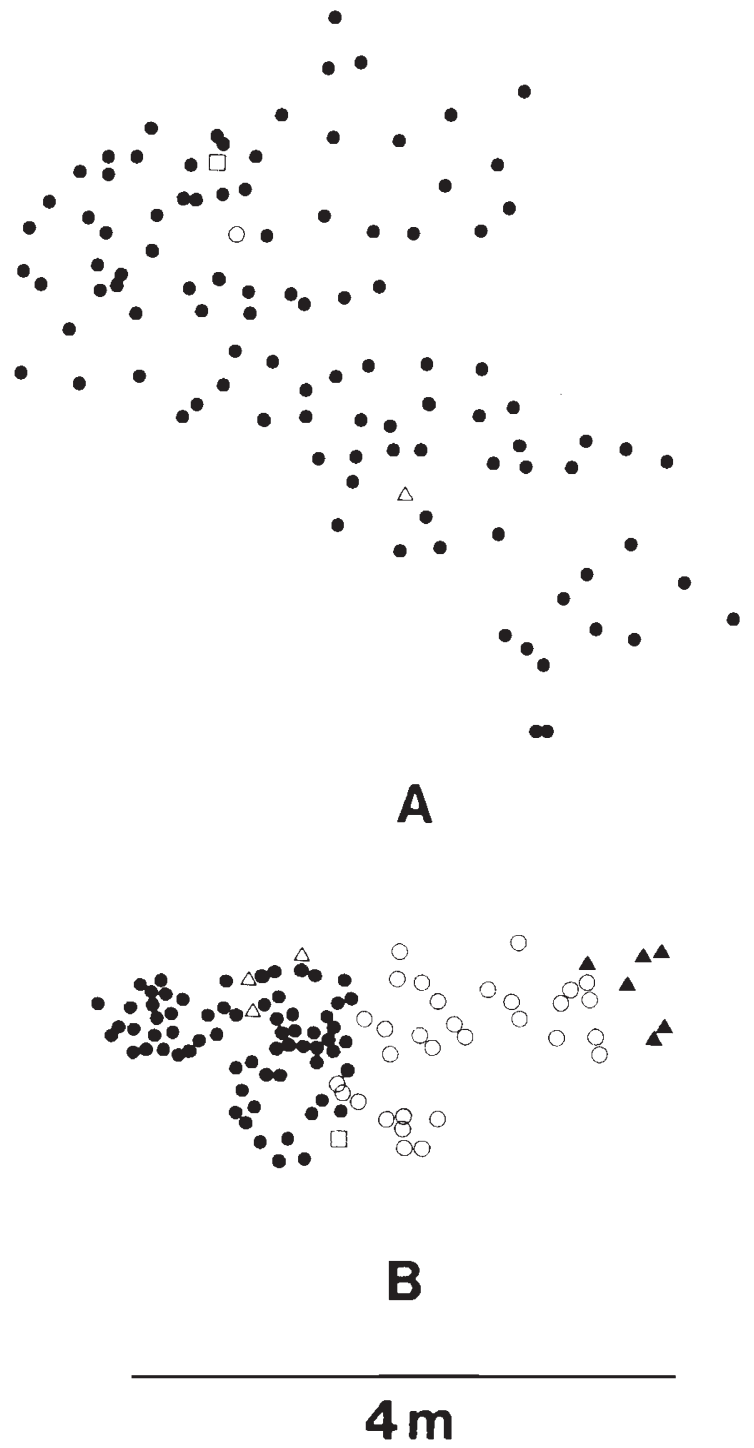

Figure 1 The pattern of genotypic distribution detected in patches A and B of Leporella fimbriata. Genotypes are indicated in the order Got-2, Est-3, Pgi and $6 P g d$, with an alpha code indicating the Pgm phenotype. Got-2 was not scored for every individual sampled in patch $B$ but the genotypes remained distinct. Patch A: (O) 34,22,22,12,A. (O) $23,23,11,22$,A. ( $\square) 24,23,22,12$,B. ( $\triangle$ ) $24,22,12,22$,A. Patch B: (O) $12,22,22,11$, A. (O) $11,24,12,11, \mathrm{~B}$. (A) $12,23,11,22$, B. $(\square)-, 22,11,-$, B. $(\triangle)-, 14,22,12$,A.

ing an area about $3 \mathrm{~m}^{2}$ (fig. 1). Three remaining genotypes were represented by one to six samples. The predominant clones were spatially dominant in this patch, with intruding genets being largely restricted to the edge of clonal boundaries. Floral morphological patterns were concordant with these patterns: careful examination of the floral morphology of 72 patches revealed only a single morphological type in 62 patches while in the remaining patches two or three morphological types were observed (Peakall, 1987).

\section{Outcrossing estimates}

Leporella fimbriata was found to be self-compatible. Crosses set more seed than selfs although the differences were not statistically significant (table 2). Similarly, the percentage of seed with embryos was higher for crosses but not statistically significant from self pollinated fruits (table 2). Pollinator movements in L. fimbriata have been found to be strongly localized with a mean of $3 \cdot 14 \pm 4 \cdot 6$ m (Peakall, 1987, 1988). Fig. 2 compares

Table 2 Comparisons of seed set and percentage of embryos between self and cross pollinated fruits of Leporella fimbriata

\begin{tabular}{llll}
\hline $\begin{array}{l}\text { Self pollination } \\
\text { Mean } \pm \text { S.D. } \\
(n \text { fruits })\end{array}$ & $\begin{array}{l}\text { Cross pollination } \\
\text { Mean } \pm \text { S.D. } \\
(n \text { fruits })\end{array}$ & $t$ & $\mathrm{df}$ \\
\hline $\begin{array}{l}\text { No. seeds set } \\
3621 \pm 514(4) \\
\% \text { embryos }\end{array}$ & $4775 \pm 599(4)$ & -1.876 & 6 n.s. \\
$78.2 \pm 28.5(8)$ & $181.4 \pm 15.7(8)$ & -0.284 & 14 n.s. \\
\hline
\end{tabular}

The percentage of embryos was based on 1822 seeds for self and 1843 seeds for cross treatments.

the distribution of pollen vector flight distances with clonal diameters and interpatch distances. Localized pollinator movement within patches which were highly clonal suggest high levels of selfing. Of flights between flowers of known genotype, some 70 per cent $(n=13)$ were within clones. In addition, revisits to these same flowers were observed (Peakall, 1988, fig. 2(a)) increasing the potential number of self pollinations to 80 per cent $(n=20)$. Overall, 88 per cent $(n=34)$ of vector flights occurred within the bounds of clonal diameters with 79 per cent being shorter than the mean clonal diameter of $2.88 \pm 1.99 \mathrm{~m}$. Only $34 \mathrm{per}$ cent of vector flight distances overlapped the minimum interclonal distances $(6.12 \pm 3 \cdot 40 \mathrm{~m}$, fig. $2)$. These data suggest that outcrossing rates rarely exceed 30 per cent and may only occur when different clones are in close proximity.

\section{Electrophoretic variation}

Allele frequencies, the fixation index $F, t$ values and results of Chi-square tests for Hardy-Weinberg equilibrium are presented in table 3. The loci Got-2 


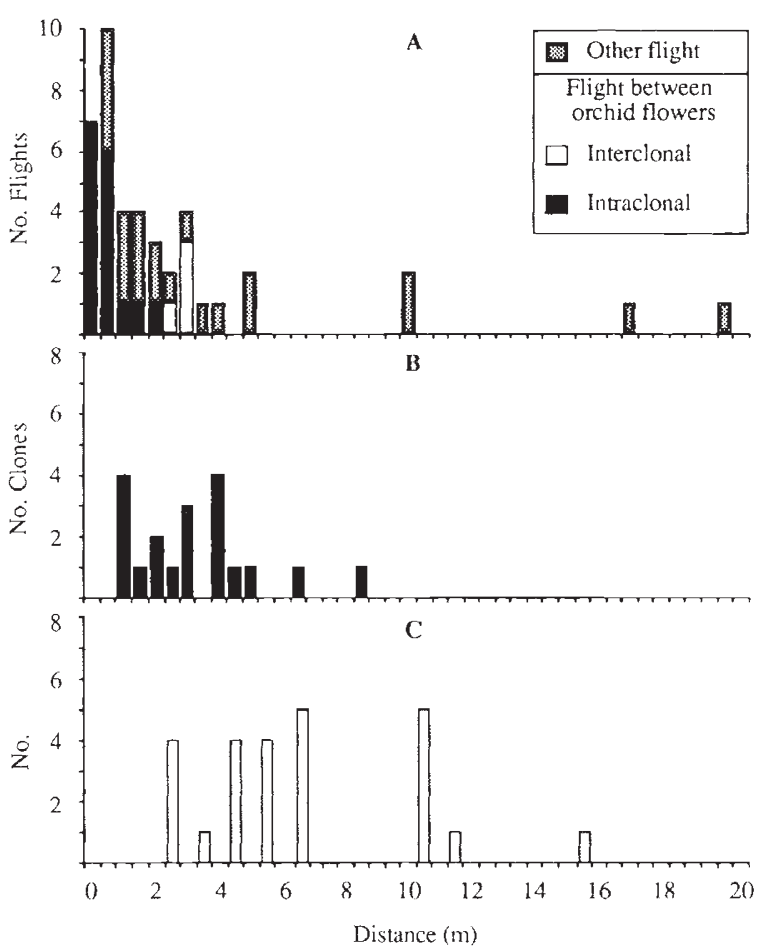

Figure 2 Frequency distributions of pollen vector flight distance, clonal diameters and interpatch distances for Leporella fimbriata. (a) Vector flight distance; other flight, includes flight between flowers of unknown genotype and between flowers and vegetation, (b) maximum clonal diameters based on electrophoretic data and (c) minimum interpatch distance.

and Est-3 were most polymorphic at the Bickley site with 4 alleles recorded for each. Only three alleles were observed for Est-3 at the nearby population of Lesmurdie, while a reduced number of alleles were observed at the two remaining sites for both Got-2 and Est-3. Only two alleles were observed for $6 \mathrm{Pgd}$ and $P g i$.

The values of $F$ varied between loci and sites, with a range of -0.25 to 0.266 (table 3 ). This variation is well within the range observed for predominantly outbreeding species (Brown, 1979). Mean values for each site were not detected to differ significantly from zero, and Chi-squared tests for Hardy-Weinberg equilibrium conformed to panmictic expectations. Single locus estimates of $t$, based on the fixation index in the absence of selection between fertilization and the adult stage, varied from 0.59 to an excess of 1.00 (table 3 ). Mean values of $t$ were close to 1 , indicative of adults derived from an predominant outbreeding system.
Gene correlation and gene diversity estimates are presented in table 4 . Values of $f$ varied from -0.103 for $P g i$ to 0.066 for $6 P g d$ with a mean of $-0 \cdot 015$. Values of $F$ were slightly higher as a result of the small contribution of $\theta$, and ranged from -0.055 for $P g i$ to 0.164 for $6 P g d$ with a mean of 0.030 . These values are typical of random mating conditions. Values of $\theta$ were low with a mean of $0 \cdot 045$, indicating relatively little differentiation between the sites and concordant with the low $F$ and $f$ values. Gene diversity statistics support these trends with most of the diversity occurring within the sites as suggested by the low mean values of 0.021 and 0.044 for $D_{\mathrm{ST}}$ and $G_{\mathrm{ST}}$ respectively (table 4 ). The mean value of $G_{\mathrm{ST}}$ was somewhat lower than the mean of 0.118 observed across 76 predominantly outcrossing species (Loveless and Hamrick, 1984).

\section{DISCUSSION}

The patterns of patch structure, composed of one or two predominant genets representing as many as several hundred ramets, suggests that the total number of genets within a population was low. For example, less than several hundred genets are expected to be represented in the estimated 12,000 ramets within 40 colonies at the Bickley site. At this site a total of 81 fruits released an estimated $324,000(81 \times 4000)$ seeds over four seasons (Peakall, 1988). This disproportionate ratio of seed production to seedling recruitment is further accentuated by the potential age of the genets within the population.

On the assumption that each ramet produces two tubers each season, and in the absence of mortality, the number of ramets within a clone increases geometrically with an expected size of $2^{n-1}$, at $n$ generations. Clones represented by 500 ramets must therefore be a minimum of ten years old. Maximum clonal diameters provide an alternative estimate of genet age. For example, at a growth rate of $10 \mathrm{~cm}$ per year (i.e., $5 \mathrm{~cm}$ in each direction, see Peakall, 1988) a clone.would take 60 years to span a diameter of $6 \mathrm{~m}$. In reality, therefore, genets such as those described for patch A (fig. 2) with as many as 500 ramets and a clonal diameter of some $6 \mathrm{~m}$, may well be in excess of 100 years old.

Observed variation in the density, distribution and number of L. fimbriata flowers from season to season (Peakall, 1988) is expected to generate some variation in the mating system from year to year. Fire may synchronize widespread flowering, 
Table 3 Allele frequencies, $F$ and $t$ values, and Chi-squared tests for Hardy-Weinberg equilibrium for populations of Leporella fimbriata

\begin{tabular}{|c|c|c|c|c|c|c|}
\hline Site (No.) & Locus & Allele freq. & $F$ & $t$ & $\mathrm{df}$ & $x^{2}$ \\
\hline \multirow[t]{5}{*}{ Bickley (50) } & Got-2 & $\begin{array}{l}1(0 \cdot 380) \\
2(0 \cdot 440) \\
3(0 \cdot 080) \\
4(0 \cdot 100)\end{array}$ & $-0 \cdot 05$ & $1 \cdot 10$ & 6 & $6 \cdot 14$ \\
\hline & Est-3 & $\begin{array}{l}1(0.060) \\
2(0.770) \\
3(0.160) \\
4(0.010)\end{array}$ & $0 \cdot 26$ & 0.59 & 6 & $7 \cdot 98$ \\
\hline & $6 P g d$ & $\begin{array}{l}1(0.430) \\
2(0.570)\end{array}$ & 0.06 & 0.89 & 1 & 0.489 \\
\hline & $P g i$ & $\begin{array}{l}1(0.350) \\
2(0.650)\end{array}$ & $-0 \cdot 10$ & $1 \cdot 20$ & 1 & $0 \cdot 489$ \\
\hline & Mean (S.E.) & & $0.04(0.08)$ & $0.95(0 \cdot 14)$ & & \\
\hline & $6 P g d$ & $\begin{array}{l}1(0.089) \\
2(0.911)\end{array}$ & $-1 \cdot 10$ & $1 \cdot 22$ & 1 & 0.270 \\
\hline & $P g i$ & $\begin{array}{l}1(0.393) \\
2(0.607)\end{array}$ & $0 \cdot 10$ & $0 \cdot 82$ & 1 & 0.289 \\
\hline & Mean (S.E.) & & $-0.03(0.05)$ & $1.09(0.11)$ & & \\
\hline \multirow[t]{3}{*}{ Kwinana (30) } & Got-2 & $\begin{array}{l}1(0.417) \\
2(0.583)\end{array}$ & -0.03 & $1 \cdot 06$ & 1 & 0.024 \\
\hline & Est -3 & $\begin{array}{l}2(0.817) \\
3(0.100) \\
4(0.083)\end{array}$ & -0.05 & $1 \cdot 11$ & 1 & 0.804 \\
\hline & $6 P g d$ & $\begin{array}{l}1(0.450) \\
2(0.550)\end{array}$ & $0 \cdot 12$ & 0.78 & 1 & 0.466 \\
\hline \multirow{4}{*}{ Lesmurdie (32) } & Est -3 & $\begin{array}{l}2(0.719) \\
3(0 \cdot 219) \\
4(0.063)\end{array}$ & $-0 \cdot 16$ & $1 \cdot 38$ & 3 & $2 \cdot 114$ \\
\hline & $6 P g d$ & $\begin{array}{l}1(0.250) \\
2(0.750)\end{array}$ & 0.00 & $1 \cdot 00$ & 1 & 0.000 \\
\hline & $P g i$ & $\begin{array}{l}1(0.469) \\
2(0.531)\end{array}$ & -0.25 & 1.67 & 1 & $2 \cdot 079$ \\
\hline & Mean (S.E.) & & $-0.11(0.05)$ & $1 \cdot 28(0 \cdot 15)$ & & \\
\hline
\end{tabular}

No significant deviations from Hardy-Weinberg expectations were detected at the 5 per cent level by Chi-squared test for any loci. No significant deviations from the null hypothesis that $F=0.0$ were detected at the 5 per cent level for mean values of $F$ for any population.

increasing the potential for cross pollination since some Leporella populations tend to flower more after fire (Peakall, 1988). In contrast, during seasons when few flowers are available, vectors may only effect selfing. In fact, vectors have been observed to effect self pollination of solitary, isolated flowers through revisitation. Overall, the mat- ing system may be expected to vary between predominate self pollination and mixed mating.

The panmictic adult population genetic structure of Leporella indicated by the electrophoretic data was not consistent with high potential for selfing apparent in this species from field pollination data. At equilibrium and in the absence of 
Table 4 Gene correlation and gene diversity statistics for Leporella fimbriata treating each of the four sites as subpopulations. Gene correlation parameters are related to $F$ statistics as $f=F_{\mathrm{IS}}, \theta=F_{\mathrm{Sr}}$, and $F=F_{\mathrm{IT}}$

\begin{tabular}{llllllll}
\hline Locus & $f$ & $\theta$ & $F$ & $H_{\mathrm{I}}$ & $H_{\mathrm{S}}$ & $D_{\mathrm{ST}}$ & $G_{\mathrm{ST}}$ \\
\hline Got -2 & -0.047 & 0.023 & -0.023 & 0.581 & 0.565 & 0.016 & 0.027 \\
Est -3 & 0.055 & 0.011 & 0.065 & 0.386 & 0.379 & 0.007 & 0.017 \\
G Pgd & 0.066 & 0.104 & 0.164 & 0.438 & 0.399 & 0.039 & 0.089 \\
Pgi & -0.103 & 0.043 & -0.055 & 0.493 & 0.473 & 0.020 & 0.041 \\
Mean $_{1}$ & $-0.015(0.15)$ & $0.045(0.04)$ & $0.030(0.24)$ & 0.475 & 0.454 & 0.021 & 0.044 \\
\hline
\end{tabular}

${ }^{1}$ (Variance) $\times 10^{2}$, estimated by jackknifing across loci, following the method of Weir and Cockerham (1984).

Table 5 Examples of significant negative changes in fixation index between life stages of plants

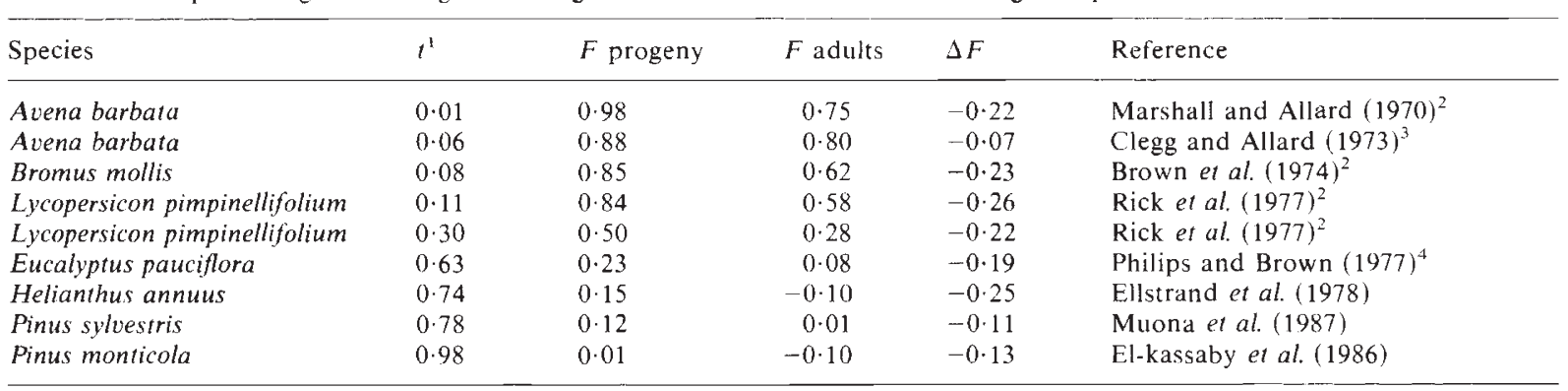

${ }^{1}$ Calculated as $t=(1-F$ progeny $) /(1+F$ progeny $)$.

${ }^{2}$ From Brown (1979).

${ }^{3}$ Mean values over three loci. Clegg and Allard treat each locus separately.

${ }^{4}$ Comparing seed with seedlings for sites 2 and 3 of study.

selection the expected fixation index $F$ for a population can be calculated as $F=(1-t) /(1+t)$ where $t$ is the outcrossing rate. Therefore, at an outcrossing rate of 30 per cent for Leporella the expected fixation index is 0.54 . The difference between the observed and expected fixation index, $\Delta F$ (Brown, 1979 ) being $-0 \cdot 54$. Significant negative $\Delta F$ values have been noted for inbreeders by Brown (1979). However, the $\Delta F$ value estimated for Leporella is much larger than observed in other species whose $\Delta F$ values varied between -0.07 for populations of Avena barbata and $-0 \cdot 26$ for populations of Lycopersicon pimpinellifolium (table 5). Even if outcrossing rates were under estimated in Leporella and actually in the order of 60 per cent, the $\Delta F$ value would still be $-0 \cdot 25$.

The disparity between the conclusions derived from pollinator movements and electrophoretic data may be explained by three interactions. First, ants are functional as pollen vectors and while mean flight distances are short, there are sufficient between clone or between patch flights to maintain low levels of outcrossing. Second, extensive seed flow is anticipated for the minute wind dispersed seeds of Leporella. Seedling establishment therefore, should be random leading to random interclonal matings. Third, the elimination of self pro- geny may lead to the appearance of panmictic adult populations. In this context of slight excess of cross seed (table 2) may be of importance as may postzygotic phenomona.

Acknowledgements We wish to thank F. Harriss for determining self-compatibility data, J. Sampson and D. Coates for valuable discussion on electrophoretic procedures and analysis, and A. J. Beattie and an anonymous reviewer for commenting on earlier drafts. This study was conducted while R. Peakall held a Commonwealth Postgraduate award.

\section{REFERENCES}

BEATTIE, A. J. 1982. Ants and gene dispersal in flowering plants. In Armstrong, J. A. (ed.) Pollination and Evolution, Royal Botanic Gardens Press, Sydney, pp. 1-8.

BROWN, A. H. D. 1979. Enzyme polymorphism in plant populations. Theor. Pop. Biol., 15, 1-2.

CHELIAK, W. M. AND PITEL, J. A. 1984. Genetic control of allozyme variants in mature tissue of white spruce trees. $J$. Hered., 75, 34-40.

CLEGG, M. T. AND ALLARD, R. W, 1973. Viability versus fecundity selection in the slender wild oat, Avena barbata L. Science, 181, 667-668.

COOK, R. F. 1983. Clonal plant populations. Am. Sci., 71, 244253.

EL-KASSABY, Y. A., MEAGHER, M. D., PARKINSON, J. AND PORTLOCK, T. 1987. Allozyme inheritance, heterozygosity and outcrossing rate among Pinus monticola near Ladysmith, British Columbia. Heredity, 58, 173-181. 
ELLSTRAND N. C., TORRES, A. M. AND LEVIN, I). A. 1978. Density and the rate of apparent outcrossing in Helianthus annuus (Asteraceae). Syst. Bot., 3, 403-407.

HANDEL, S. N. 1985. The intrusion of clonal growth patterns on plant breeding systems, Am. Nat., 125, 367-384.

HICKMAN, J. C. 1974. Pollination by ants: a low energy system. Science, 184, 1290-1292.

JAIN, S. K. 1979. Estimation of outcrossing rates: Some alternative procedures. Crop $S_{c i}$, 19, 23-24.

LOVELESS, M. D. AND HAMRICK, J. L. 1984. Ecological determinants of genetic structure in plant populations. Ann. Rev. Ecol. Syst., 15, 65-95.

MARSHALL, D. R. AND ALLARI, R. W. 1970. Maintenance of isozyme polymorphisms in natural populations of Avena barbata. Genetics, 66, 393-399.

MORAN, G. F. AND HOPPER, S. D. 1983. Genetic diversity and the insular population structure of the rare granite rock species, Eucalyptus caesia Benth. Aust. J. Bot., 31, 161-172.

MUONA, O., YAZDABU, R. AND RUDIN, D. 1987. Genetic change between life stages in Pinus sylvestrix, allozyme variation in seeds and planted seedlings. Silvae Genetica, 36, 39-42.

NEI, M. 1973. Analysis of gene diversity in subdivided populations. Proc. Nat. Acad. Sci. USA, 70, 3321-3323.

PEAKALL R. 1987. Genetic Systems of Australian Terrestrial Orchids. Ph.D. Thesis, University of Western Australia.

PEAKALL, R. 1988. The unique pollination of Leporella fimbriata (Lindley, A. S. George (Orchidaceae) by pseudocopulating winged male ants Myrmecia urens (Formicidae). In press.

PEAKALL, R., BEATTIE, A. J. AND JAMES, S. H. 1987. Pseudocopulation of an orchid by male ants: A test of two hypotheses accounting for the rarity of ant pollination. Oecologia, 73, 522-524.
PHILIPS, M. A. AND BROWN, A. H. D. 1977. Mating system and hybridity in Eucalyptus pauciflora. Aust. J. Biol. Sci., 30, $337-344$.

RICK, C. M., FOBES, J. F. AND HOLLE, M. 1977. Genetic variation in Lycopersicon pimpinellifolium: evidence of evolutionary change in mating systems Pl. Syst. Evol., 127, 139-170.

SELANDER, R. K., SMITH, M. H., YANG, S. Y. AND JOHNSON W. F. 1971. Biochemical polymorphism and systematics in the genus Peromyscus I. Variation in the old-field mouse Peromyscus polionotus. In Studies in Genetics VI, University of Texas Publication, pp. 49-70.

SHAW, C. R. AND PRASAD, R. 1970. Starch gel electrophoresis of enzymes: A compilation of recipes. Biochem. Genet., 4 , $297-320$.

SHIELDS, C. R., ORTON, T. J. AND STUBER, C. W. 1983. An outline of general resource needs and procedures for the electrophoretic separation of active enzymes from plant tissue. In Tanksley, S. D. and Orton, T. J. (eds) Isozymes in Plant Genetics and Breeding, Part A, Elsevier, Amsterdam, pp. 423-441.

SILANDER, J. A. 1979. Microevolution and clone structure in Spartina patens. Science, 203, 658-660.

SWOFFORD, D. L. AND SELANDER, R. B. 1981. BIOSYS-1: a FORTRAN program for the comprehensive analysis of electropinoretic data in population genetics and systematics J. Hered., 72, 281-283.

WEIR, B. S. AND COCKERHAM, C. C. 1984. Estimating F-statistics for the analysis of population structure. Evol., 38, 1358-1370.

Wright, S. 1951. The genetical structure of populations. Ann. Eugenics, 15, 323-354. 